\title{
Induction of MMP-1 and -3 by cyclical mechanical stretch is mediated by IL-6 in cultured fibroblasts of keratoconus
}

\author{
GEN-LAI DU ${ }^{1}$, WEI-YI CHEN ${ }^{1}$, XIAO-NA LI ${ }^{1}$, RUI HE $^{2}$ and PENG-FEI FENG ${ }^{1}$ \\ ${ }^{1}$ Shanxi Key Lab of Material Strength \& Structural Impact, Taiyuan University of Technology, Taiyuan, \\ Shanxi 030024; ${ }^{2}$ Department of Excimer Laser, Shanxi Eye Hospital, Taiyuan, Shanxi 030002, P.R. China
}

Received December 9, 2016; Accepted March 16, 2017

DOI: $10.3892 / \mathrm{mmr} .2017 .6433$

\begin{abstract}
In order to understand the effect of mechanical stretch on corneal extracellular matrix remodeling, human keratoconus fibroblasts (HKCFBs) were subjected to cyclic stretch in vitro and the expression of matrix metalloproteinases (MMPs), tissue inhibitor of metalloproteinases (TIMPs), and inflammatory cytokines were evaluated. HKCFBs were seeded into a flexible membrane base and subjected to a cyclic stretch regimen of $10 \%$ equibiaxial stretch at a stretching frequency of $1 \mathrm{~Hz}$ for $6 \mathrm{~h}$ using a Flexcell tension unit. An antibody directed against interleukin-6 (IL-6 Ab) was used to investigate the roles of IL- 6 on mechanical stretch mediated regulation of MMP in HKCFBs. Culture supernatants were assayed using an enzyme-linked immunosorbent assay for MMP-1 and -3, TIMP-1 and -2, and IL-6. Total RNA from the cells was extracted, and quantitative polymerase chain reaction was used to determine mRNA for MMP-1 and -3 , TIMP-1 and -2, and IL-6. In stretched cells, levels of MMP-1 and -3 demonstrated an increase compared with unstretched cells, but levels of TIMP-1, and -2 revealed a decrease. Mechanical stretch significantly increased the mRNA expression and protein synthesis of IL- 6 compared with unstretched cells. IL-6 induced MMP-1 and -3 expression, whereas no significant effects were observed in levels of TIMP-1 and -2 compared with the untreated control groups. Additionally, the IL-6 Ab markedly inhibited the stretch-induced increase in MMP-1 and -3 in culture supernatants in a dose-dependent manner. No significant differences in TIMP-1 and -2 protein levels were detected between stretched cells treated with IL-6 $\mathrm{Ab}$ and stretched cells without IL-6 Ab treatment. These results indicate that cyclical mechanical stretch augments IL-6 production and MMP expression, and reduces levels of
\end{abstract}

Correspondence to: Professor Wei-Yi Chen, Shanxi Key Lab of Material Strength \& Structural Impact, Taiyuan University of Technology, 79 Yingze West Street, Taiyuan, Shanxi 030024, P.R. China

E-mail: chenweiyi@tyut.edu.cn

Key words: keratoconus, mechanical stretch, IL-6, MMPs, TIMPs
TIMP in HKCFBs. Thus, it is suggested that IL-6 mediates the stretch-induced MMP expression.

\section{Introduction}

Keratoconus is a progressive disease characterized by thinning and protrusion of the cornea, resulting in an irregular, conical shape (1). The characteristics of keratoconus have been known for at least 200 years, but causes of keratoconus have not been clearly established. Case reports showed associations between keratoconus and atopy (2), allergy (3), family history (4), other systemic genetic disorders (4), contact lens wear (5), exposure to ultraviolet radiation (6), eye-rubbing (7), disorders of enzyme function (6), and epithelial trauma and the production of inflammatory mediators (8). However, in a multivariate analysis of keratoconus risk factors, eye-rubbing was the most significant predictor for the development and/or progression of this disease (9).

Two large studies of keratoconus indicated that approximately $50 \%$ of subjects reported frequent, chronic, vigorous or abnormal rubbing of at least one eye $(10,11)$. Vigorous eye-rubbing in keratoconus has been shown to be up to 10 times more forceful than normal eye-rubbing $(12,13)$. Previous studies have found that the values of corneal biomechanical measurements are significantly lower in keratoconic eyes than in normal eyes $(14,15)$. A study of the application of experimental digital forces to human eyes revealed that, for an open eye with normal intraocular pressure (IOP) of $15 \mathrm{~mm} \mathrm{Hg}$, light and firm digital forces increased IOP by 100 and 300\%, respectively (16). The IOP in keratoconus responses may be greater when more force is used and rubbing episodes are longer. In addition, some studies have reported that the human cornea is a viscoelastic tissue (17) and depending on the nature of mechanical forces to which the human cornea is subjected, there may be an (almost) instantaneous deformation, which is the elastic part of the viscoelasticity $(18,19)$. We therefore hypothesized that human keratoconus fibroblasts (HKCFBs) within the intraocular environment may be lengthened in response to the dynamic forces applied to the cornea caused by constant changes in the levels of IOP.

Matrix metalloproteinases (MMPs) are a family of zinc-dependent enzymes that are responsible for the degradation of extracellular matrix (ECM) and connective tissue protein (20). Elevated levels of MMPs are found in keratoconus 
corneas, and considerable degradation of the extracellular matrix occurs, indicating that MMPs may be involved in the pathogenesis of keratoconus (21-25). Tissue inhibitors of metalloproteinases (TIMPs) inhibit the activity of MMPs by binding to them (20). The balance between the MMPs and TIMPs determines the extent of proteolysis linked with tissue remodeling or degradation of ECM components including collagen and elastin (20).

Several studies have suggested that many diseases have been associated with an imbalance of ECM synthesis and degradation and mechanical factors have been found involved in the pathogenesis of these diseases $(26,27)$. Mechanical stimulation is involved in the regulation of MMPs in some ocular tissues, such as sclera (28), trabecular meshwork (29) and lamina cribrosa cells (30). The cornea is a dynamic tissue, capable of altering its ECM composition and biomechanical properties in response to changes in the visual environment $(31,32)$. In addition, corneal fibroblasts have been demonstrated to respond actively to local tension changes in the ECM (33), and fibroblasts are a major type of mechanoresponsive cell (34). However, to date, there have been no reports regarding the effect of mechanical stretch on expression of MMP and TIMP in HKCFBs.

In our experiment, HKCFBs were subjected to cyclical mechanical stretch in vitro and the expression of MMP-1, MMP-3, TIMP-1, and TIMP-2 were evaluated. The present study appears to be the first experimental evidence to show significantly induced levels of MMP and reduced levels of TIMP in HKCFBs after mechanical stretch, thereby providing support for the possible association between the thinning and ectasia of a keratoconus cornea and mechanical stretch. In addition, we used IL-6 antibody (IL-6 Ab) to examine the role of IL-6 on stretch mediated regulation of MMP in HKCFBs. Results indicated that IL- 6 may be a potential mediator of stretch-induced effects on expression of MMP and IL-6 Ab might provide a new modality to prevent further progression of some forms of keratoconus.

\section{Materials and methods}

Isolation and cell culture. Keratoconus cornea was collected from patient with keratoconus (a 16 year old donor) who was undergoing corneal transplantation within 6-12 h following surgery from Shanxi Eye Hospital (Tai yuan, Shanxi, China). The study was undertaken with the approval of the local ethics committee and after obtaining written informed consent from patient. The epithelium and endothelium of cornea were mechanically removed. The corneal stroma was cut into several pieces with diameter of $1.0 \mathrm{~mm}$. Subsequently, the small tissue pieces were digested into single cells with DMEM/F12 medium containing $2 \mathrm{mg} / \mathrm{ml}$ of type II collagenase. Cells were cultured in DMEM/F12 containing fetal bovine serum and in an air $-5 \% \mathrm{CO}_{2}$ incubator at $37^{\circ} \mathrm{C}$. Experiments were performed using $\mathrm{HKCFBs}$ from passages 3-5.

Mechanical stretch application. For experiment, HKCFBs were seeded at 6-well Bioflex ${ }^{\circledR}$ plates (Flexcell Int. Corp., Hillsborough, NC, USA) with an initial density of $5 \times 10^{5} /$ well. After the cells reached subconfluency, the cells were serum starved using DMEM/F12 with 0.1\% FBS for $24 \mathrm{~h}$. After $24 \mathrm{~h}$, the media was replaced with FBS-free media (DMEM/F12). HKCFBs were then subjected to cyclical stretch $(1 \mathrm{~Hz})$ at $10 \%$ maximum elongation for $6 \mathrm{~h}$ using a Flexcell ${ }^{\circledR}$ Tension Plus $^{\mathrm{TM}}$ FX-4000 ${ }^{\mathrm{TM}}$ system (Flexcell Int. Corp., Hillsborough, $\mathrm{NC}$, USA) at $37^{\circ} \mathrm{C}$ in a humidified incubator with an atmosphere containing $5 \% \mathrm{CO}_{2}$. Cells plated on Bioflex ${ }^{\circledR}$ plates but not subjected to stretch served as controls. At the end of the experiment, the cells and supernatants from cell cultures were collected for gene or protein detection, respectively.

Treatment with IL-6. The relationship between IL-6 and expression of MMP and TIMP was investigated. HKCFBs were seeded at 6-well Bioflex ${ }^{\circledR}$ plates (Flexcell Int. Corp., Hillsborough, NC, USA) with an initial density of $5 \times 10^{5} /$ well. When the cultured cells became confluent, the cells were serum starved using DMEM/F12 with $0.1 \%$ FBS for $24 \mathrm{~h}$. After $24 \mathrm{~h}$, the media was replaced with FBS-free media (DMEM/F12) and treated with IL-6 (R\&D Systems, Minneapolis, MN, USA) at a final concentration of $0,12.5,25$ or $50 \mathrm{ng} / \mathrm{ml}$. The cells were cultured for $6 \mathrm{~h}$. No significant cytotoxic effect on cell proliferation (data not shown). At the end of the experiment, the cells and supernatants from cell cultures were collected for gene or protein detection, respectively.

Effect of IL-6 Ab. IL-6 Ab (Peprotech, Rocky Hill, NJ, USA) was used to determine if mechanical stretch-induced expression of MMP by HKCFBs was mediated by IL-6. The stretch experiments were repeated in the presence and absence of a IL-6 Ab $(15,30$ or $60 \mathrm{ng} / \mathrm{ml})$. No significant cytotoxic effect on cell proliferation (data not shown). At the end of the experiment, the supernatants from cell cultures were collected for protein detection.

Real-time polymerase chain reaction (RT-PCR). The procedure used for RT-PCR was similar to that described elsewhere. Briefly, total RNA was extracted by TRIzol reagent (Invitrogen, Carlsbad, CA, USA) according to manufacturer-recommended procedures. $1 \mu \mathrm{g}$ of RNA was converted to cDNA with the PrimeScript $^{\mathrm{TM}}$ RT reagent Kit (TaKaRa Biotechnology CO., Dalian, China) by gradient PCR device (Eppendorf, Germany). Reverse transcription was performed for $2 \mathrm{~min}$ at $42^{\circ} \mathrm{C}, 15 \mathrm{~min}$ at $37^{\circ} \mathrm{C}$, and $5 \mathrm{sec}$ at $85^{\circ} \mathrm{C}$, followed by cooling to $4^{\circ} \mathrm{C}$. Then, $2 \mu \mathrm{l}$ of 30 -fold-diluted cDNA products were amplified with SYBR ${ }^{\circledR}$ Premix Ex Taq ${ }^{\mathrm{TM}}$ II $(\mathrm{TaKaRa}$ Biotechnology CO) by the StepOnePlus ${ }^{\mathrm{TM}}$ RT-PCR System (Applied Biosystems, USA) using the gene specific primers (Table I) designed by Shanghai Sangon Biotechnology Co., Ltd. (Shanghai, China). For quantification, all target mRNA expression were normalized to the expressed housekeeping gene glyceraldehyde-3-phosphate dehydrogenase (GAPDH). RT-PCR conditions were as follows: $95^{\circ} \mathrm{C}$ for $30 \mathrm{sec}$ and then 40 cycles at $95^{\circ} \mathrm{C}$ for $5 \mathrm{sec}, 60^{\circ} \mathrm{C}$ for $30 \mathrm{sec}$, and $72^{\circ} \mathrm{C}$ for $1 \mathrm{~min}$, followed by $72^{\circ} \mathrm{C}$ for $10 \mathrm{~min}$. The relative quantity of mRNA was calculated using the $2^{-\Delta \Delta \mathrm{C}_{\mathrm{T}}}$ method, in which $\mathrm{C}_{\mathrm{T}}$ is the threshold cycle. The resulting data were expressed as a ratio to the control value denoted as one.

Enzyme-linked immunosorbent assay (ELISA). Human MMP-1, MMP-3, TIMP-1, TIMP-2, and IL-6 ELISA kits (BioSource International, Camarillo, CA, USA) were used to 
Table I. Primer sequences for RT-PCR.

\begin{tabular}{|c|c|}
\hline Gene & 5'-3' sequences (forward; reverse) \\
\hline MMP-1 & $\begin{array}{l}\text { For: GGGAGATCATCGGGACAACTC } \\
\text { Rev: GGGCCTGGTTGAAAAGCAT }\end{array}$ \\
\hline MMP-3 & $\begin{array}{l}\text { For: TGGCATTCAGTCCCTCTATGG } \\
\text { Rev: AGGACAAAGCAGGATCACAGTT }\end{array}$ \\
\hline TIMP-1 & $\begin{array}{l}\text { For: TTGTTGCTGGGCTGATAGC } \\
\text { Rev: CAGGATTCAGGCTATCTGGG }\end{array}$ \\
\hline TIMP-2 & $\begin{array}{l}\text { For: GCACATCACCCTCTGTGACTT } \\
\text { Rev: AGCGCGTGAT CTT GCACT }\end{array}$ \\
\hline IL-6 & $\begin{array}{l}\text { For: CCTGAACCTTCCAAAGATGGC } \\
\text { Rev: CTTGGGGTTCTTGCTGATGT }\end{array}$ \\
\hline GAPDH & $\begin{array}{l}\text { For: AAGGTCGGAGTGAACGGATTTG } \\
\text { Rev: TTCACCAGGCAAGTCTCCTCA }\end{array}$ \\
\hline
\end{tabular}

MMP, matrix metalloproteinases; TIMP, tissue inhibitor of metalloproteinases; IL-6,interleukin-6;GAPDH, glyceraldehyde-3-phosphate dehydrogenase.

measure levels of MMP-1, MMP-3, TIMP-1, TIMP-2, and IL-6 in the cell supernatants according to the manufacturer's recommendations. The optical density was measured at $450 \mathrm{~nm}$ in a microplate reader (Multiskan Go, Thermo Scientific, USA).

Statistical analysis. All results were presented as the mean \pm standard deviation of three independent experiments and statistically performed by using SPSS v.19.0 software and one-way analysis of variance (ANOVA) analysis. $\mathrm{P}<0.05$ was considered to denote a statistically significant difference.

\section{Results}

Cyclical stretch up-regulates MMP-1 and -3 and down-regulates TIMP-1 and -2 . The results indicated that the mRNA expression of MMP-1 and -3 were up-regulated by the cyclic stretch, while in contrast the mRNA expression of TIMP-1 and -2 were down-regulated by the cyclic stretch. The ratios of stretch to nonstretched control values of MMP-1, MMP-3, TIMP-1, and TIMP-2 were 3.07 $\pm 0.31,2.83 \pm 0.22$, $0.44 \pm 0.04$, and $0.61 \pm 0.04$, respectively $(\mathrm{P}<0.05$; Fig. $1 \mathrm{~A})$.

The concentrations of MMP-1 and -3 in cell culture supernatants showed an increase in stretched cells relative to unstretched cells, while in contrast the concentrations of TIMP-1 and -2 showed a decrease in stretched cells compared to unstretched cells: MMP-1 in unstretched cells, $419.27 \pm 33.58 \mathrm{ng} / \mathrm{ml}$, and stretched cells, $486.48 \pm 26.32 \mathrm{ng} / \mathrm{ml}$ $(\mathrm{P}<0.05)$; MMP-3 in unstretched cells, 217.44 $\pm 12.08 \mathrm{ng} / \mathrm{ml}$, and stretched cells, 270.34 $\pm 10.15 \mathrm{ng} / \mathrm{ml}(\mathrm{P}<0.05)$; TIMP-1 in unstretched cells, 204.94 $\pm 10.67 \mathrm{ng} / \mathrm{ml}$, and stretched cells, $176.06 \pm 8.58 \mathrm{ng} / \mathrm{ml}(\mathrm{P}<0.05)$; and TIMP-2 in unstretched cells, $31.65 \pm 2.45 \mathrm{ng} / \mathrm{ml}$, and stretched cells, $19.51 \pm 1.55 \mathrm{ng} / \mathrm{ml}$ $(\mathrm{P}<0.05$; Fig. 1B).

Cyclical stretch increases concentration ratios of MMP/TIMP. The MMP/TIMP ratios in cell culture supernatants were increased in stretched cells relative to unstretched cells: MMP-1/TIMP-1 ratio in unstretched cells was $2.05 \pm 0.24$ and $2.77 \pm 0.23$ in stretched cells $(\mathrm{P}<0.05$; Fig. $2 \mathrm{~A})$; MMP-1/TIMP-2 ratio in unstretched cells was $13.28 \pm 1.05$ compared to $25.14 \pm 2.13$ in stretched cells $(\mathrm{P}<0.05$; Fig. $2 \mathrm{~A})$; MMP-3/TIMP-1 ratio in unstretched cells was $1.06 \pm 0.07$ as opposed to $1.55 \pm 0.09$ in stretched cells $(\mathrm{P}<0.05$; Fig. $2 \mathrm{~B})$; MMP-3/TIMP-2 ratio in unstretched cells was $6.89 \pm 0.56$ compared with $12.96 \pm 1.32$ in stretched cells $(\mathrm{P}<0.05$; Fig. 2B).

Cyclical stretch causes secretion of IL-6. Cyclical stretch augmented IL- 6 mRNA expression and protein synthesis. The ratio of stretch to nonstretched control mRNA value of IL-6 was 3.21 $\pm 0.24(\mathrm{P}<0.05$; Fig. 3A). It was found that the mean concentration of IL- 6 in cell culture supernatants rose from $7.12 \pm 0.58 \mathrm{ng} / \mathrm{ml}$ before stretch to $9.77 \pm 0.85 \mathrm{ng} / \mathrm{ml}$ after stretch $(\mathrm{P}<0.05$; Fig. 3B).

IL-6 induces MMP-1 and -3 expression. Fig. 4A showed that MMP-1 and -3 mRNA expression were enhanced in the presence of IL- 6 with a dose-dependent manner. The ratios of mRNA for MMP-1 and -3 to IL-6-untreated control were 2.35 \pm 0.21 and $1.78 \pm 0.13$ at a concentration of $12.5 \mathrm{ng} / \mathrm{ml}, 6.64 \pm 0.58$ and $4.65 \pm 0.41$ at $25 \mathrm{ng} / \mathrm{ml}$, and $7.87 \pm 0.74$ and $6.23 \pm 0.49$ at $50 \mathrm{ng} / \mathrm{ml}$, respectively $(\mathrm{P}<0.05)$.

As shown in Fig. 4B, IL-6 induced MMP-1 and -3 protein synthesis in a dose-dependent manner. Similarly, the ratios of protein for MMP-1 and -3 to IL-6-untreated control were $1.27 \pm 0.09$ and $1.25 \pm 0.08$ at a concentration of $12.5 \mathrm{ng} / \mathrm{ml}, 1.58 \pm 0.11$ and $1.66 \pm 0.12$ at $25 \mathrm{ng} / \mathrm{ml}$, and $1.98 \pm 0.13$ and $2.22 \pm 0.17$ at $50 \mathrm{ng} / \mathrm{ml}$, respectively $(\mathrm{P}<0.05)$.

In addition, no significant differences or changes were observed in mRNA and protein levels of TIMP-1 and -2 between cells treated with and without IL-6 (P>0.05; Fig. 4).

IL-6 Ab inhibits stretch-induced MMP-1 and -3 expression. As depicted in Fig. 5A, the protein expression of MMP-1 and -3 induced by mechanical stretch were significantly reduced in a dose-dependent manner by the specific IL-6 Ab treatment. IL-6 Ab markedly decreased mechanical stretch-induced MMP-1 and -3 protein production by $16 \pm 1.2$ and $18 \pm 1.4 \%$ at a concentration of $15 \mathrm{ng} / \mathrm{ml}, 35 \pm 2.9$ and $54 \pm 4.9 \%$ at $30 \mathrm{ng} / \mathrm{ml}$, and $51 \pm 4.5$ and $68 \pm 6.1 \%$ at $60 \mathrm{ng} / \mathrm{ml}$, respectively $(\mathrm{P}<0.05)$. Additionally, TIMP-1 and -2 concentrations reduced by mechanical stretch were not affected by the addition of IL-6 $\mathrm{Ab}(\mathrm{P}>0.05$; Fig. 5B).

IL-6 Ab down-regulates concentration ratios of MMP/TIMP. The fact that decreases in mechanical stretch-induced MMP-1 and -3 secretion after IL-6 Ab treatment were not accompanied by changes in the amount of secreted TIMP-1 and -2 , resulted in shifting the MMP/TIMP ratios. For example, concentration ratios of MMP-1/TIMP-1 and MMP-1/TIMP-2 showed decrease in cells stretched in the presence of IL-6 Ab relative to the IL- $6 \mathrm{Ab}$-untreated stretched cells by $13 \pm 0.9$ and $17 \pm 1.3 \%$ at a concentration of $15 \mathrm{ng} / \mathrm{ml}, 27 \pm 2.2$ and $42 \pm 3.6 \%$ at $30 \mathrm{ng} / \mathrm{ml}$, and $61 \pm 5.5$ and $56 \pm 4.3 \%$ at $60 \mathrm{ng} / \mathrm{ml}$, respectively $(\mathrm{P}<0.05$; Fig. 5C). Similarly, a significant reduction was demonstrated for the MMP-3/TIMP-1 and MMP-3/TIMP-2 ratios in stretched cells treated with IL-6 Ab, compared with the IL- 6 Ab-untreated stretched cells by $14 \pm 1.0$ and $21 \pm 1.6 \%$ at 

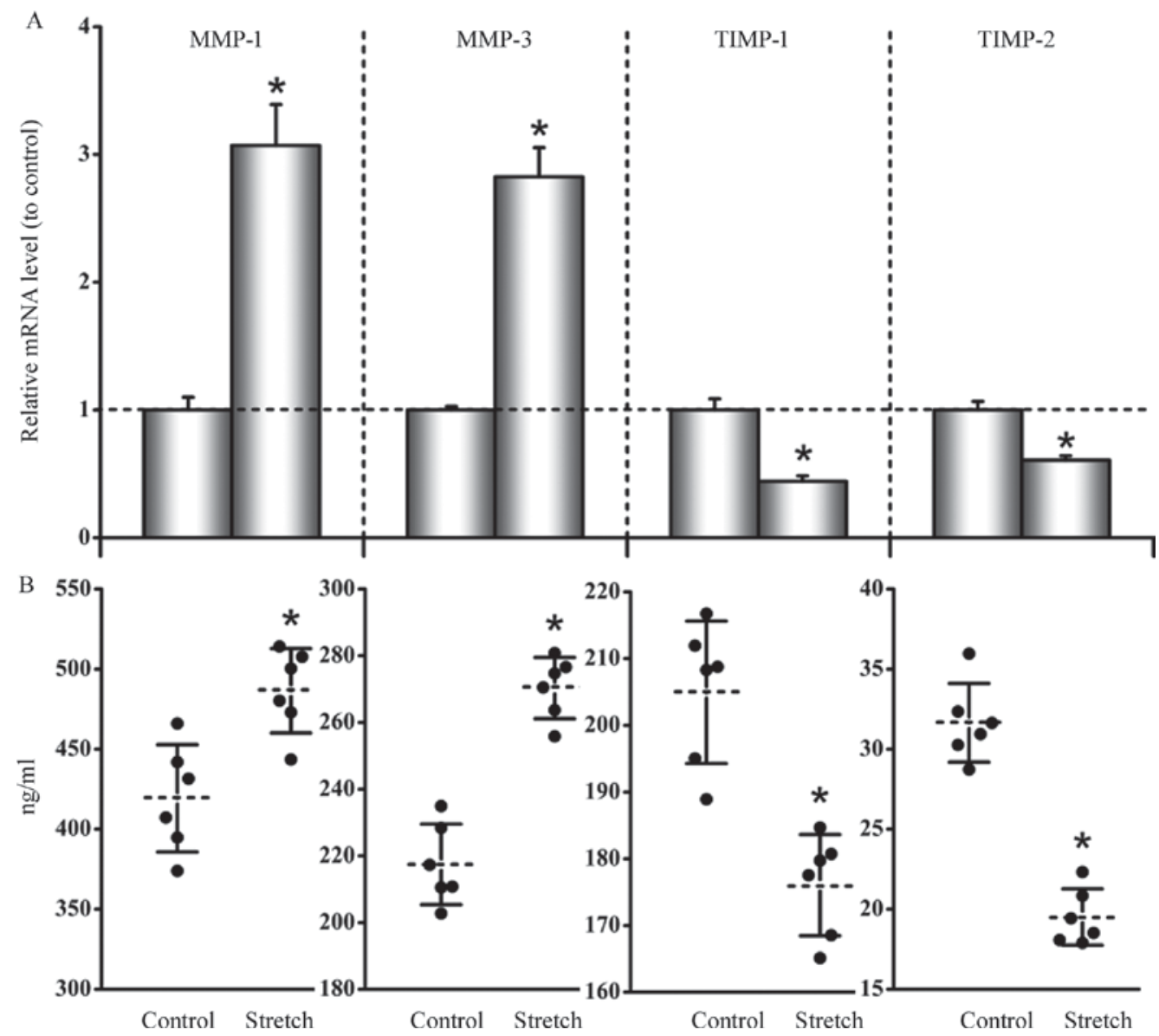

Figure 1. Effect of cyclical mechanical stretch on MMP and TIMP levels in HKCFBs. Cells were subjected to cyclical stretch for $6 \mathrm{~h}$. Total RNA and cell-culture supernatants were then collected. mRNA levels determined by RT-PCR from total RNA and protein levels measured using human ELISA kits from cell-culture supernatants. (A) The MMP-1 and -3 mRNA expression were increased in stretched cells relative to unstretched cells. But in stretched cells, TIMP-1 and -2 mRNA expression showed a decrease compared to unstretched cells. (B) The concentrations of MMP-1 and -3 in culture supernatants showed an increase in stretched cells as opposed to unstretched cells, while in contrast the concentrations of TIMP-1 and -2 decreased in stretched cells compared to unstretched cells. Data are represented as the mean \pm standard deviation ( $\mathrm{n}=6$ per group). ${ }^{*} \mathrm{P}<0.05$, stretched vs. nonstretched control. MMP, matrix metalloproteinases; TIMP, tissue inhibitor of metalloproteinases; HKCFBs, human keratoconus fibroblasts.

a concentration of $15 \mathrm{ng} / \mathrm{ml}, 47 \pm 4.1$ and $59 \pm 5.5 \%$ at $30 \mathrm{ng} / \mathrm{ml}$, and $67 \pm 5.8$ and $69 \pm 6.2 \%$ at $60 \mathrm{ng} / \mathrm{ml}$, respectively $(\mathrm{P}<0.05$; Fig. 5D).

\section{Discussion}

It might be thought that the eye-rubbing is coincidental and not causal, but the large proportion of keratoconus giving a history of chronic habits of abnormal eye-rubbing appeared leaves little doubt that chronic and abnormal eye-rubbing may cause the cornea to give way and is also possibly responsible for the progression of some forms of keratoconus (7). Based on the above hypothesis, we speculate that corneal stromal fibroblasts may be exposed to mechanical stress caused by abnormal chronic eye-rubbing in some patients with keratoconus. In vitro cell stretch systems have rapidly become standard models for studying the effects of mechanical forces on a variety of cell types, including scleral fibroblasts (28), trabecular meshwork cells (29) and lamina cribrosa cells (30). These studies have attempted to model intraocular forces by introducing mechanical distortion (4-15\% amplitude strain) to ocular cells for static or dynamic $(0.3 \mathrm{~Hz}$ or $1 \mathrm{~Hz})$ loading for $30 \mathrm{~min}-72 \mathrm{~h}(28-30)$. Because the forces exerted at the cornea represent transient changes in force caused by constant changes in the levels of IOP, we selected a stretch protocol for HKCFBs in vitro employing a regimen of cyclical dynamic stretch. In our study, flexible-bottom culture dishes were subjected to distension, using the Flexcell $^{\circledR}$ Tension Plus ${ }^{\mathrm{TM}} \mathrm{FX}^{\mathrm{T}}-4000^{\mathrm{TM}}$ system to deliver a highly controlled regimen of sinusoidal stretch with a strain amplitude of $10 \%$ at a frequency of $1 \mathrm{~Hz}$ (60 cycles per min) for $6 \mathrm{~h}$.

In the human eye, studies of MMPs and TIMPs have been performed in the aqueous humor (35), vitreous (36), retina (37), trabecular meshwork (38), keratoconus corneas (39), and corneas during wound healing (40). Large studies have revealed a relationship between mechanical stretch and MMPs and TIMPs in many kinds of eye cells. For example, Shelton et al (28) reported that mechanical strain increased levels of MMP-2 and reduced levels of TIMP-2 by human scleral fibroblasts. Kirwan et al (30) reported that cyclical stretch induced MMP-2 expression in human lamina cribrosa cells. Mechanically stretched trabecular meshwork cells have reported increases in MMP-2 protein and gene expression $(29,41)$, increased MMP-14 protein levels (29), and either no change or a decrease in TIMP-2 $(29,42)$. In these cultured cells, mechanical stretch shifted the MMP-TIMP balance and 

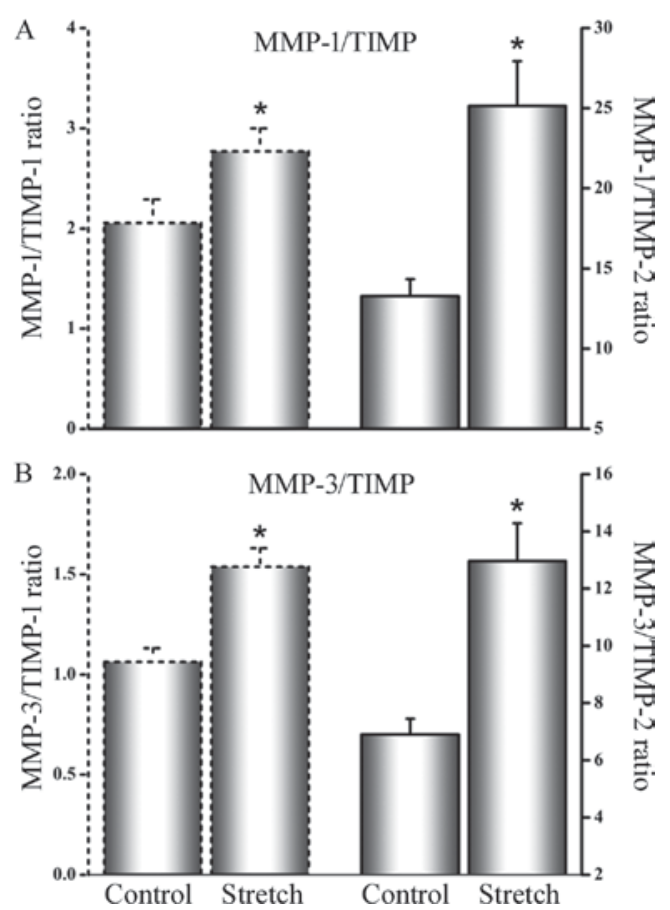

Figure 2. Effect of cyclical mechanical stretch on MMP/TIMP ratios in culture supernatants of HKCFBs. Concentration ratios of (A) MMP-1/TIMP-1, MMP-1/TIMP-2, (B) MMP-3/TIMP-1, and MMP-3/TIMP-2 were higher in stretched cells than in unstretched cells. Data are represented as the mean \pm standard deviation ( $\mathrm{n}=6$ per group). ${ }^{*} \mathrm{P}<0.05$, stretched vs. nonstretched control. MMP, matrix metalloproteinases; TIMP, tissue inhibitor of metalloproteinases; $\mathrm{HKCFBs}$, human keratoconus fibroblasts.
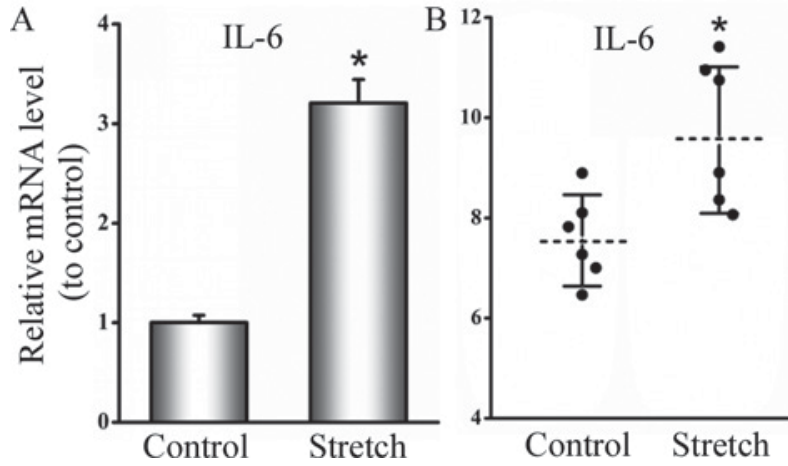

Figure 3. Effect of cyclical mechanical stretch on IL-6 mRNA expression and protein synthesis in HKCFBs. Cells were subjected to cyclical stretch for $6 \mathrm{~h}$. Total RNA and cell-culture supernatants were then collected. mRNA levels assayed by RT-PCR from total RNA and protein levels measured using a human IL-6 ELISA kit from cell-culture supernatants. (A) The mRNA expression of IL-6 were induced by the cyclical stretch. (B) IL-6 production increased by cells during mechanical cyclical stretch, compared with the nonstretched cells. Data are represented as the mean \pm standard deviation ( $n=6$ per group). ${ }^{*} \mathrm{P}<0.05$, stretched vs. nonstretched control. IL-6, interleukin-6; HKCFBs, human keratoconus fibroblasts.

these results suggest mechanical stretch may be involved in the pathogenesis of these diseases $(29,30)$.

MMP-1, -2, -3, -7, -9 and -13 have been found to be elevated in the tear film of patients with keratoconus $(22-25,43,44)$ and decreased levels of TIMP-1 have been found in keratoconus corneas and their cell cultures $(6,45)$, indicating that MMPs and TIMPs may be involved in the pathogenesis of keratoconus. Our studies have focused primarily on MMP-1, MMP-3,
TIMP-1, and TIMP-2. To the best of our knowledge, this was the first investigation to determine the effect of cyclical mechanical stretch on MMP-1, MMP-3, TIMP-1 and TIMP-2 mRNA expression and protein synthesis in $\mathrm{HKCFBs}$ in vitro.

Our data showed that mechanical stretch increased MMP-1 and -3 production and decreased TIMP-1 and -2 production, resulting in an increased MMP-1/TIMP-1 ratio, MMP-1/TIMP-2 ratio, MMP-3/TIMP-1 ratio, and MMP-3/TIMP-2 ratio. MMP-1, an interstitial collagenase, can degrade native fibrillar collagen types I, II, III, IX, and XI (20). MMP-3, or stromelysin-1, has a broad substrate specificity that includes casein, proteoglycans, fibronectin, elastin, and laminin, as well as collagen types III, IV, V, IX, and IX (20). Type I and type III collagen accounts for about $85 \%$ of corneal ECM (46). Keratoconus corneal stroma has decreased levels of type I, III, V, XII and VI collagens (47). Therefore, it is conceivable that the increase in the ratios of MMP/TIMP by stretched HKCFBs may facilitate the degradation of the corneal ECM. A balance between ECM synthesis and degradation is a prerequisite for maintaining the structural and functional integrity of the cornea (27). Moreover, previous studies have revealed that the thinning and ectasia of a keratoconus cornea has been mainly attributed to the increased degradation of ECM $(21,25,48)$. Since keratoconus is characterized by the thinning of the corneal stroma, taken together, the up-regulation of MMP/TIMP ratios caused by mechanical stretch which may represent one of the main causes of the damage of corneal tissue, thereby contribute to the development and/or progression of some forms of keratoconus.

Keratoconus is defined as a non-inflammatory disease of the cornea, however, in recent years, several groups have demonstrated that the tear film in keratoconus showed increased levels of inflammatory molecules (IL-4, -5, -6, -8, TNF- $\alpha,-\beta)$ compared with normal controls $(22,23,25,49)$. The extent of the increase was found to be associated with the severity of keratoconus $(22,23,49)$. This suggested that the pathogenesis of keratoconus may involve chronic inflammatory events.

IL-6 is a pleiotropic cytokine with a wide range of biological activities in immune regulation, hematopoiesis, inflammation and oncogenesis and IL- 6 could play an important role in the generation of inflammation within the cornea (50). A recent study has indicated that IL-6 may rank as important factors in the pathogenesis of keratoconus (25). Previous studies have documented the effect of mechanical stretch on IL- 6 synthesis in a variety of cell types (51). Additionally, IL-6 can modulate the expression of MMPs and TIMPs by human corneal epithelial cells (52). However, to date, there have been no reports regarding the correlation between mechanical stretch and IL-6 expression and the effect of IL- 6 on the production of MMPs and TIMPs in HKCFBs.

Our study showed that cyclical stretch increased IL-6 levels, and we also found IL-6 induced MMP-1 and -3 expression in a dose-dependent manner, but did not modify TIMP-1 and TIMP-2 levels, indicating that IL-6 induces a increase of the MMP/TIMP ratios in HKCFBs. The synthesis of larger amounts of IL-6 by epithelial cells could influence a number of immunity and inflammation activities which could lead to corneal damage within the eye (53). We postulate that IL-6 may play a role in the degradation of ECM in 


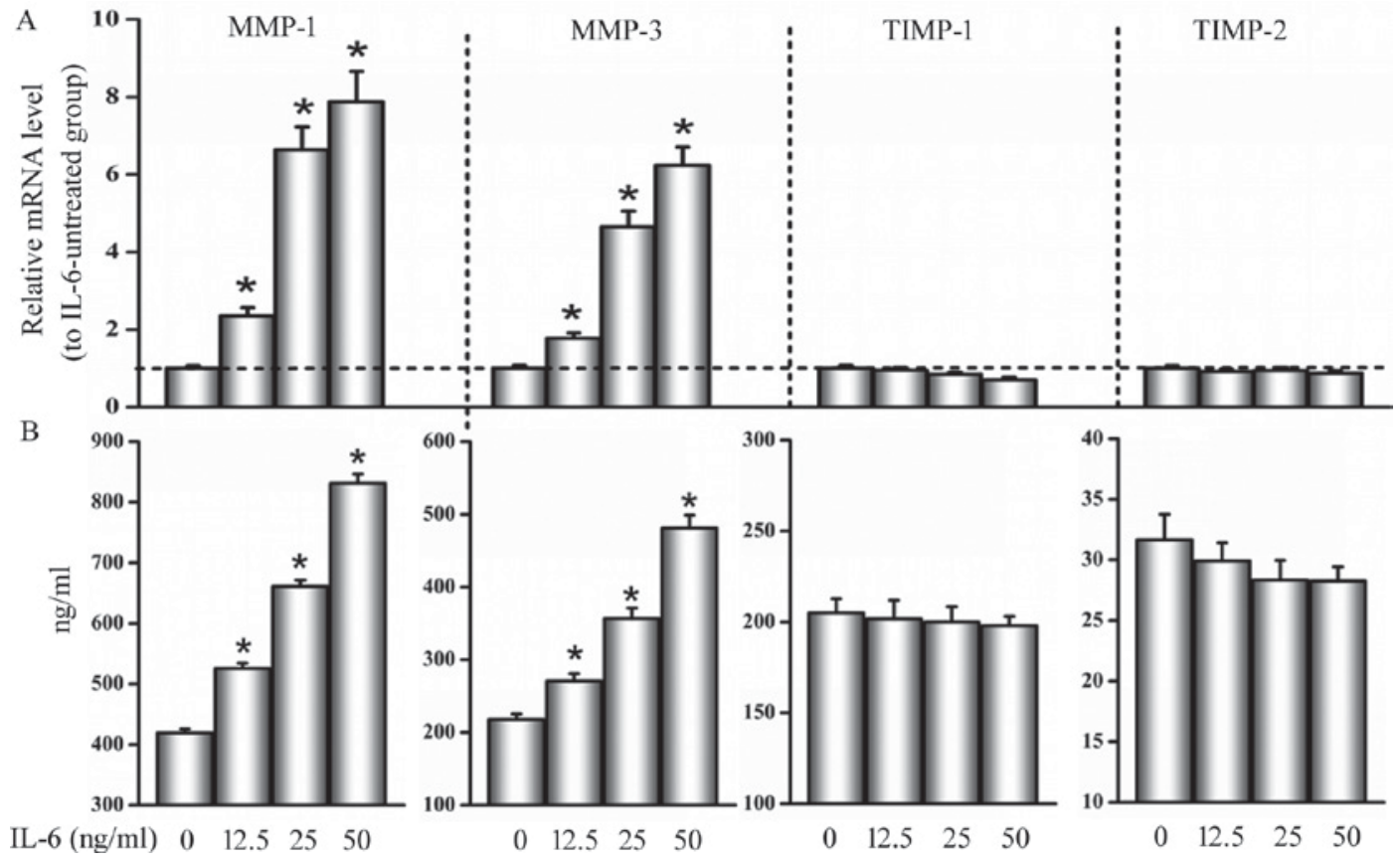

Figure 4. Effect of IL-6 on MMP and TIMP expression in HKCFBs. Cells were treated with IL- 6 for $6 \mathrm{~h}$ at the indicated concentration. Total RNA and cell-culture supernatants were then collected. mRNA levels determined by RT-PCR from total RNA and protein levels measured using human ELISA kits from cell-culture supernatants. (A) The MMP-1 and -3 mRNA expression were up-regulated in cells treated with IL-6 relative to IL-6-untreated group. No significant differences were observed in mRNA levels of TIMP-1 and -2 between cells treated with and without IL-6. (B) IL-6 enhanced protein synthesis for MMP-1 and -3, whereas no significant effects were observed in protein levels of TIMP-1 and -2 . Data are represented as the mean \pm standard deviation (n=6 per group). "P<0.05, IL-6-treated vs. IL-6-untreated control. IL-6, interleukin-6; MMP, matrix metalloproteinases; TIMP, tissue inhibitor of metalloproteinases; HKCFBs, human keratoconus fibroblasts.
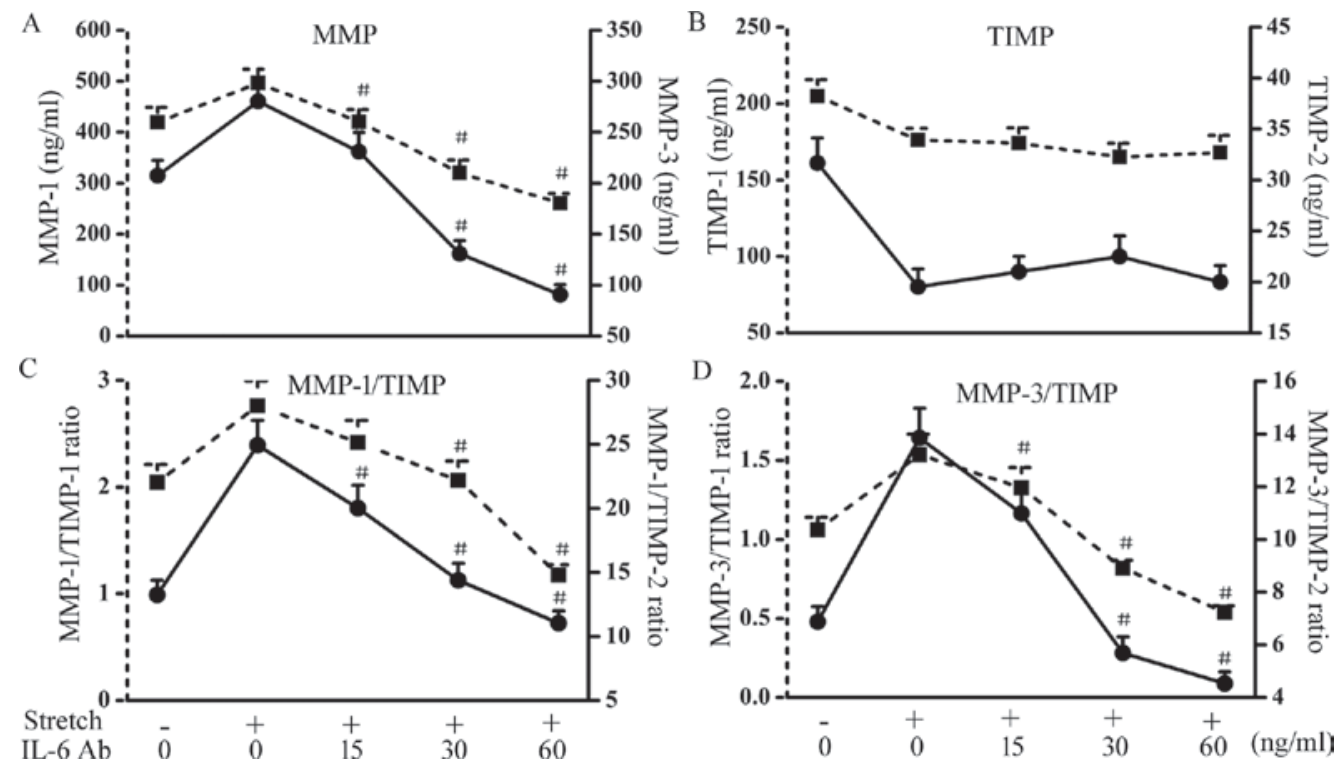

Figure 5. Effect of IL-6 Ab on MMP and TIMP concentrations and the concentration ratios of MMP/TIMP in culture supernatants of stretched HKCFBs. The stretch experiments were repeated in the presence of various IL-6 Ab concentrations. Cell-culture supernatants were then collected and protein levels were detected by human ELISA kits. (A) The increased MMP-1 and -3 protein levels in cell culture supernatants of stretched cells were inhibited during IL-6 $\mathrm{Ab}$ treatment. (B) No significant differences in TIMP-1 and -2 concentrations were observed in the culture medium of stretched cultures with the absence or presence of IL-6 Ab. The up-regulated concentration ratios of (C) MMP-1/TIMP-1, MMP-1/TIMP-2, (D) MMP-3/TIMP-1, and MMP-3/TIMP-2 in cell culture supernatants of stretched cells were down-regulated during IL-6 Ab treatment. Data are represented as the mean \pm standard deviation (n=6 per group). ${ }^{\text {" }} \mathrm{P}<0.05$, stretch in the presence of IL-6 Ab vs. stretched effect without IL-6 Ab. IL-6 Ab, interleukin-6 antibody; MMP, matrix metalloproteinases; TIMP, tissue inhibitor of metalloproteinases; HKCFBs, human keratoconus fibroblasts.

keratoconus corneas by up-regulating the MMP/TIMP ratios. Balasubramanian et al (54) used specific ELISA to measure the amount of inflammatory markers $60 \mathrm{sec}$ after eye-rubbing in normal subjects. They found an increased expression in tear
MMP-13, IL-6 and TNF- $\alpha$ in normal subjects. These inflammatory changes after eye-rubbing are thought contribute to the pathogenesis. Put together, our results provide further support for that the pathogenesis of keratoconus may involve chronic 
inflammatory events and matrix degradation. Moreover, the mechanical stress caused by eye-rubbing may be a cause of development of inflammatory events and matrix degradation in some types of keratoconus.

Wang et al (55) reported that TNF- $\alpha$ mediates the stretch-induced MMP genes expression in human umbilical vein endothelial cells. TNF- $\alpha$ is also widely considered an important cytokine mediator of inflammation and immune regulation that can cause a range of local and systemic biological effects in various cell types (56). Similarly, we speculate that the stretch-induced MMP expression in HKCFBs is dependent on IL-6. In our experiment, IL-6 Ab was used to determine whether mechanical stretched-induced MMP by HKCFBs was mediated by IL-6. Our data showed that the stretch-induced expression of MMP-1 and -3 were markedly inhibited in the presence of IL- $6 \mathrm{Ab}$, whereas no significant changes in TIMP-1 and -2 protein levels were detected in stretched cells with the presence or absence of the IL-6 Ab. Moreover, the IL-6 Ab inhibited significantly the stretch-induced increase in MMP-1 and -3 in culture supernatants in a dose-dependent manner.

Previous work reported that heat shock can increase MMP-1 and -3 and IL- 6 at both the mRNA and protein levels in cultured skin fibroblasts and the expression of MMP-1 and -3 increased by heat shock significantly were blocked after treatment with a monoclonal antibody against IL-6, indicating that IL-6 mediates the heat shock-induced MMP-1 and -3 expression (57). Similarly, our study demonstrates that mechanical stretch up-regulated MMP-1 and -3 expression via IL-6 in HKCFBs.

A recent study has found that subsequent treatment of keratoconus patients with cyclosporine A (CyA) reduced tear MMP-9 levels significantly and led to local reduction in corneal curvatures, indicating that $\mathrm{CyA}$ might be a novel treatment strategy in keratoconus (58). In addition, it is worth mentioning that several IL-6 blocking agents such as a humanized anti-IL-6 receptor antibody has been developed and successfully applied in clinical trials for the treatment of several diseases $(59,60)$.

Our data showed that MMP/TIMP ratios up-regulated by cyclical stretch were attenuated by IL-6 Ab in a dose-dependent manner. A significant reduction in the MMP/TIMP ratios by IL-6 Ab might provide a new modality to treat patients with keratoconus.

Further studies are required to determine which signaling pathway being involved in the process: Stretch $\rightarrow$ IL- $6 \rightarrow$ MMP in keratoconus. It is possible that inhibiting IL-6 may help to dampen degradation of the corneal ECM mediated by mechanical stretch thereby reducing damage to the cornea. This may be realized by inhibiting IL-6 receptors or inhibition of targets downstream of the IL- 6 signaling pathway or other pathways targeting IL-6 for treating keratoconus.

In conclusion, our findings indicate that cyclically mechanical stretch induces levels of MMP-1 and -3 and IL-6 and reduces levels of TIMP-1 and -2 in HKCFBs; IL- 6 mediates the stretch-induced MMP expression in keratoconus.

\section{Acknowledgements}

This study was financially supported by the National Natural Science Foundation of China (grant no. 11402161, 11402162, 11572213, 31300770, 31271005).

\section{References}

1. Rabinowitz YS: Keratoconus. Surv Ophthalmol 42: 297-319, 1998.

2. Harrison RJ, Klouda PT, Easty DL, Manku M, Charles J and Stewart CM: Association between keratoconus and atopy. Br J Ophthalmol 73: 816-822, 1989.

3. McMonniesc CW and Boneham GC: Keratoconus, allergy, itch, eye-rubbing and hand-dominance. Clin Exp Optom 86: 376-384, 2003.

4. Szczotka-Flynn L, Slaughter M, Mcmahon T, Barr J, Edrington T, Fink B, Lass J, Belin M and Iyengar SK; CLEK Study Group: Disease severity and family history in keratoconus. Br J Ophthalmol 92: 1108-1111, 2008.

5. McMonnies CW: The biomechanics of keratoconus and rigid contact lenses. Eye Contact Lens 31: 80-92, 2005.

6. Cristina Kenney M and Brown DJ: The cascade hypothesis of keratoconus. Cont Lens Anterior Eye 26: 139-146, 2003.

7. Ridley F: Eye-rubbing and contact lenses. Br J Ophthalmol 45: 631, 1961 .

8. Wilson SE, He YG, Weng J, Li Q, McDowall AW, Vital M and Chwang EL: Epithelial injury induces keratocyte apoptosis: Hypothesized role for the interleukin-1 system in the modulation of corneal tissue organization and wound healing. Exp Eye Res 62: 325-327, 1996

9. Bawazeer AM, Hodge WG and Lorimer B: Atopy and keratoconus: A multivariate analysis. Br J Ophthalmol 84: 834-836, 2000.

10. Zadnik K, Barr JT, Edrington TB, Everett DF, Jameson M, McMahon TT, Shin JA, Sterling JL, Wagner $\mathrm{H}$ and Gordon MO: Baseline findings in the collaborative longitudinal evaluation of keratoconus (CLEK) study. Invest Ophthalmol Vis Sci 39: 2537-2546, 1998

11. Weed KH, MacEwen CJ, Giles T, Low J and McGhee CN: The Dundee university Scottish keratoconus study: Demographics, corneal signs, associated diseases, and eye rubbing. Eye (Lond) 22: 534-541, 2008

12. Korb D, Leahy C and Greiner J: Prevalence and characteristics of eye-rubbing for keratoconic and non-keratoconic subjects. Invest Ophthalmol Vis Sci 32: 1057, 1991.

13. McMonnies CW: Abnormal rubbing and keratectasia. Eye Contact Lens 33: 265-271, 2007.

14. Ortiz D, Piñero D, Shabayek MH, Arnalich-Montiel F and Alió JL: Corneal biomechanical properties in normal, post-laser in situ keratomileusis, and keratoconic eyes. J Cataract Refract Surg 33: 1371-1375, 2007.

15. Shah S, Laiquzzaman M, Bhojwani R, Mantry S and Cunliffe I: Assessment of the biomechanical properties of the cornea with the ocular response analyzer in normal and keratoconic eyes. Invest Ophthalmol Vis Sci 48: 3026-3031, 2007.

16. McMonnies CW and Boneham GC: Corneal curvature stability with increased intraocular pressure. Eye Contact Lens 33: 130-137, 2007.

17. Schwartz NJ, Mackay RS and Sackman JL: A theoretical and experimental study of the mechanical behavior of the cornea with application to the measurement of intraocular pressure. Bull Math Biophys 28: 585, 1966.

18. Humphrey JD and Delange SL: An introduction to biomechanics: Solids and fluids, analysis and design. Springer, New York, NY, pp1293-1293, 2007.

19. Liu WC, Lee SM, Graham AD and Lin MC: Effects of eye rubbing and breath holding on corneal biomechanical properties and intraocular pressure. Cornea 30: 855-860, 2011.

20. Visse R and Nagase H: Matrix metalloproteinases and tissue inhibitors of metalloproteinases: Structure, function, and biochemistry. Circ Res 92: 827-839, 2003.

21. Collier SA: Is the corneal degradation in keratoconus caused by matrix-metalloproteinases? Clin Exp Ophthalmol 29: 340-344, 2001.

22. Lema I and Durán JA: Inflammatory molecules in the tears of patients with keratoconus. Ophthalmology 112: 654-659, 2005.

23. Lema I, Sobrino T, Durán JA, Brea D and Díez-Feijoo E: Subclinical keratoconus and inflammatory molecules from tears. Br J Ophthalmol 93: 820-824, 2009.

24. Balasubramanian SA, Pye DC and Willcox MD: Are proteinases the reason for keratoconus? Curr Eye Res 35: 185-191, 2010.

25. Balasubramanian SA, Mohan S, Pye DC and Willcox MD: Proteases, proteolysis and inflammatory molecules in the tears of people with keratoconus. Acta Ophthalmol 90: e303-e309, 2012. 
26. Sun HB: Mechanical loading, cartilage degradation, and arthritis Ann N Y Acad Sci 1211: 37-50, 2010.

27. Lenz O, Elliot SJ and Stetler-Stevenson WG: Matrix metalloproteinases in renal development and disease. J Am Soc Nephrol 11: 574-581, 2000

28. Shelton L and Rada JS: Effects of cyclic mechanical stretch on extracellular matrix synthesis by human scleral fibroblasts. Exp Eye Res 84: 314-322, 2007.

29. Bradley JM, Kelley MJ, Zhu X, Anderssohn AM, Alexander JP and Acott TS: Effects of mechanical stretching on trabecular matrix metalloproteinases. Invest Ophthalmol Vis Sci 42: 1505-1513, 2001

30. Kirwan RP, Fenerty CH, Crean J, Wordinger RJ, Clark AF and O'Brien CJ: Influence of cyclical mechanical strain on extracellular matrix gene expression in human lamina cribrosa cells in vitro. Mol Vis 11: 798-810, 2005.

31. Petroll WM, Cavanagh HD and Jester JV: Dynamic three-dimensional visualization of collagen matrix remodeling and cytoskeletal organization in living corneal fibroblasts. Scanning 26: 1-10, 2004

32. Grabner G, Eilmsteiner R, Steindl C, Ruckhofer J, Mattioli R and Husinsky W: Dynamic corneal imaging. J Cataract Refract Surg 31: 163-174, 2005.

33. Petroll WM, Vishwanath $\mathrm{M}$ and Ma L: Corneal fibroblasts respond rapidly to changes in local mechanical stress. Invest Ophthalmol Vis Sci 45: 3466-3474, 2004.

34. Derderian CA, Bastidas N, Lerman OZ, Bhatt KA, Lin SE, Voss J, Holmes JW, Levine JP and Gurtner GC: Mechanical strain alters gene expression in an in vitro model of hypertrophic scarring. Ann Plast Surg 55: 69-75, 2005.

35. Määttä M, Tervahartiala T, Harju M, Airaksinen J, Autio-Harmainen $\mathrm{H}$ and Sorsa T: Matrix metalloproteinases and their tissue inhibitors in aqueous humor of patients with primary open-angle glaucoma, exfoliation syndrome, and exfoliation glaucoma. J Glaucoma 14: 64-69, 2005.

36. Takano A, Hirata A, Inomata Y, Kawaji T, Nakagawa K, Nagata S and Tanihara H: Intravitreal plasmin injection activates endogenous matrix metalloproteinase- 2 in rabbit and human vitreous. Am J Ophthalmol 140: 654-660, 2005.

37. Flaxel C, Bradle J, Acott T and Samples JR: Retinal pigment epithelium produces matrix metalloproteinases after laser treatment. Retina 27: 629-634, 2007.

38. Pang IH, Hellberg PE, Fleenor DL, Jacobson N and Clark AF: Expression of matrix metalloproteinases and their inhibitors in human trabecular meshwork cells. Invest Ophthalmol Vis Sci 44: 3485-3493, 2003.

39. Predović J, Balog T, Marotti T, Gabrić N, Bohac M, Romac I and Dekaris I: The expression of human corneal MMP-2, MMP-9, proMMP-13 and TIMP-1 in bullous keratopathy and keratoconus. Coll Antropol 32: 15-19, 2008

40. Daniels JT, Geerling G, Alexander RA, Murphy G, Khaw PT and Saarialho-Kere U: Temporal and spatial expression of matrix metalloproteinases during wound healing of human corneal tissue. Exp Eye Res 77: 653-664, 2003.

41. Vittal V, Rose A, Gregory KE, Kelley MJ and Acott TS: Changes in gene expression by trabecular meshwork cells in response to mechanical stretching. Invest Ophthalmol Vis Sci 46: 2857-2868 2005.

42. Lubis AM and Lubis VK: Matrix metalloproteinase, tissue inhibitor of metalloproteinase and transforming growth factor-beta 1 in frozen shoulder, and their changes as response to intensive stretching and supervised neglect exercise. J Orthop Sci 18: 519-527, 2013
43. Mackiewicz Z, Määttä M, Stenman M, Konttinen L, Tervo T and Konttinen YT: Collagenolytic proteinases in keratoconus. Cornea 25: 603-610, 2006.

44. Pannebaker C, Chandler HL and Nichols JJ: Tear proteomics in keratoconus. Mol Vis 16: 1949-1957, 2010

45. Kenney MC, Chwa M, Atilano SR, Tran A, Carballo M, Saghizadeh M, Vasiliou V, Adachi W and Brown DJ: Increased levels of catalase and cathepsin V/L2 but decreased TIMP-1 in keratoconus corneas: Evidence that oxidative stress plays a role in this disorder. Invest Ophthalmol Vis Sci 46: 823-832, 2005.

46. Karamichos D, Funderburgh ML, Hutcheon AE, Zieske JD, $\mathrm{Du}$ Y, Wu J and Funderburgh JL: A role for topographic cues in the organization of collagenous matrix by corneal fibroblasts and stem cells. PLoS One 9: e86260, 2014.

47. Chaerkady R, Shao H, Scott SG, Pandey A, Jun AS and Chakravarti S: The keratoconus corneal proteome: Loss of epithelial integrity and stromal degeneration. J Proteomics 87: 122-131, 2013.

48. Matthews FJ, Cook SD, Majid MA, Dick AD and Smith VA: Changes in the balance of the tissue inhibitor of matrix metalloproteinases (TIMPs)-1 and -3 may promote keratocyte apoptosis in keratoconus. Exp Eye Res 84: 1125-1134, 2007.

49. Jun AS, Cope L, Speck C, Feng X, Lee S, Meng H, Hamad A and Chakravarti S: Subnormal cytokine profile in the tear fluid of keratoconus patients. PLoS One 6: e16437, 2011.

50. Field G, Conn CA, McClanahan TB, Nao BS, Kluger MJ and Gallagher KP: Tumor necrosis factor and interleukin-6 are not elevated in venous blood from ischemic canine myocardium. Proc Soc Exp Biol Med 206: 384-391, 1994.

51. Kanwar YS, Wada J, Sun L, Xie P, Wallner EI, Chen S, Chugh S and Danesh FR: Diabetic nephropathy: Mechanisms of renal disease progression. Exp Biol Med (Maywood) 233: 4-11, 2008.

52. Tang $\mathrm{CH}$, Chen $\mathrm{CF}$, Chen WM and Fong YC: IL-6 increases MMP-13 expression and motility in human chondrosarcoma cells. J Biol Chem 286: 11056-11066, 2011.

53. Cubitt CL, Lausch RN and Oakes JE: Differences in interleukin-6 gene expression between cultured human corneal epithelial cells and keratocytes. Invest Ophthalmol Vis Sci 36: 330-336, 1995.

54. Balasubramanian SA, Pye DC and Willcox MD: Effects of eye rubbing on the levels of protease, protease activity and cytokines in tears: Relevance in keratoconus. Clin Exp Optom 96: 214-218, 2013.

55. Wang BW, Chang H, Lin S, Kuan P and Shyu KG: Induction of matrix metalloproteinases-14 and -2 by cyclical mechanical stretch is mediated by tumor necrosis factor-alpha in cultured human umbilical vein endothelial cells. Cardiovasc Res 59: 460-469, 2003

56. Tracey KJ and Cerami A: Tumor necrosis factor and regulation of metabolism in infection: Role of systemic versus tissue levels. Proc Soc Exp Biol Med 200: 233-239, 1992

57. Park CH, Lee MJ, Ahn J, Kim S, Kim HH, Kim KH, Eun HC and Chung JH: Heat shock-induced matrix metalloproteinase (MMP)-1 and MMP-3 are mediated through ERK and JNK activation and via an autocrine interleukin-6 loop. J Invest Dermatol 123: 1012-1019, 2004.

58. Shetty R, Ghosh A,Lim RR, Subramani M, Mihir K, Reshma AR, Ranganath A, Nagarai S, Nuijts RM, Beuerman R, et al: Elevated expression of matrix metalloproteinase- 9 and inflammatory cytokines in keratoconus patients is inhibited by cyclosporine $\mathrm{A}$. Invest Ophthalmol Vis Sci 56: 738-750, 2015.

59. Jones SA: Directing transition from innate to acquired immunity: Defining a role for IL-6. J Immunol 175: 3463-3468, 2005.

60. Nishimoto $\mathrm{N}$ and Kishimoto T: Interleukin 6: From bench to bedside. Nat Clin Pract Rheumatol 2: 691-691, 2006. 